UDC 330.3:657.012

JEL: E02, E60, 011

\section{Nika Ilkova}

Prydniprovska State Academy of Civil Engineering and

Architecture, Dnipro, Ukraine E-mail: expert_dndise@ukr.net orcid.org/0000-0002-7255-397X

\section{Natalia Rinkevich}

Prydniprovska State Academy of Civil Engineering and

Architecture, Dnipro, Ukraine

E-mail: starnarysharm@gmail.com orcid.org/0000-0002-1229-6051

Received: September, 2018 Accepted: November, 2018

DOI:10.31520/2616-7107/2018.2.4-1

(C) Economics. Ecology. Socium, 2018 CC BY-NC 4.0 license

\section{External conditions of bankruptcy institute functioning in the economy of Ukraine}

Introduction. In modern conditions of Ukrainian economy development, it is interesting to justify certain measures to support enterprises in the conditions of national economy dependence on fluctuations in the world market and the inflation growth, in order to ensure the stability of business entity functioning in all spheres of the economy. Under such circumstances, effective bankruptcy institute functioning becomes of particular importance, since the possibility of industrial production growth, employment level increase and people life quality improvement depends on the financial recovery of enterprises of real sector economy.

Aim and tasks. The aim of the article is to study external conditions of bankruptcy Institute functioning in the economy of Ukraine and their modern transformation. The obtained results determine what exactly should be done in the direction of further improvement of the regulatory instruments of state policy in this area. To achieve the goal, it has been used a complex of scientific research complementary methods of economic processes and phenomena, with an application of statistical and analytical materials, as well as the results of authors scientific research.

Results. As a result of a study of external conditions of bankruptcy Institute functioning in the economy of Ukraine, it is determined that existing macroeconomic environment has a significant impact on its character of functioning, defining the goals and objectives of further transformation processes regulation. It is determined that the external factors of the macroeconomic environment are the most threatening because there is almost no opportunity to influence them at the enterprise level. In the research, the peculiarities of the external conditions of bankruptcy Institute functioning in the economy of Ukraine are identified based on the use of indicators that directly or indirectly help determine the effectiveness of bankruptcy institute, the laws of its development, and interaction of social, political, economic and other processes at the macro level.

Conclusions. On the basis of the obtained results, it can be determined that most indicators testify difficult external conditions of bankruptcy institute functioning, with a certain improvement of the situation in recent years. Thereby, there is a need for further bankruptcy institute transformation, in order to maintain the balance between the interests of the state, economic entities, competitive market environment, and entrepreneurial activity risk minimization.

Keywords: bankruptcy institute, Ukrainian economy, crisis, the world economy, external environment, state policy. 
УДК: 330.3:657.012

JEL: E02, E60, 011

\section{Ніка Ількова}

ДВНЗ «Придніпровська державна академія будівництва та архітектури» м. Дніпро, Україна E-mail: expert_dndise@ukr.net orcid.org/0000-0002-7255-397X

\section{Наталля Ринкевич}

ДВНЗ «Придніпровська державна академія будівництва та архітектури»

м. Дніпро, Україна

E-mail: starnarysharm@gmail.com orcid.org/0000-0002-1229-6051

Отримано: Вересень, 2018

Прийнято: Листопад, 2018

DOI: $10.31520 / 2616-7107 / 2018.2 .4-1$

(C) Економіка. Екологія. Соціум, 2018 CCBY-NC 4.0ліцензія

\section{Зовнішні умови функціонуванні інституту банкрутства в економіці України}

Вступ. В сучасних умовах розвитку української економіки викликає інтерес обгрунтування цілеспрямованих заходів 3 підтримки підприємств в умовах залежності національної економіки від коливань на світовому ринку, зростання інфляції, 3 метою забезпечення стабільності функціонування організаційно-правових форм господарювання в усіх сферах економіки. В цих умовах ефективне функціонування інституту банкрутства набуває особливого значення, так як від фінансового оздоровлення підприємств реального сектора економіки залежить можливість забезпечення зростання промислового виробництва, збільшення зайнятості населення та поліпшення якості життя людей.

Мета та завдання. Метою статті $є$ дослідження зовнішніх умов функціонування інституту банкрутства в економіці України ma ïx сучасну трансформацію. Отримані висновки дозволять визначити, що саме треба робити у напрямку подальшого удосконалення регулятивних інструментів державної політики у цій сфері. Для досягнення мети використано комплекс взаємодоповнюючих методів наукового дослідження економічних процесів та явищ 3 використанням статистичних й аналітичних матеріалів, а також результати власних наукових досліджень.

Результати. В результаті дослідження зовнішніх умов функціонування інституту банкрутства в економіці України було визначено, що існуюче макроекономічне середовище чинить суттєвий вплив на характер його функціонування, визначаючи цілі i завдання подальшого регулювання процесами трансформації. Визначено, що зовнішні чинники макроекономічного середовища $\epsilon$ найбільш загрозливими за рахунок майже відсутньої можливості вплинути на них на рівні підприємства. В процесі дослідження ідентифіковано особливості зовнішніх умов функціонування інституту банкрутства в українській економіці на основі використання показників, які прямо або опосередковано дозволяють визначати дієвість інституту банкрутства, закономірності його розвитку, а також взаємовплив соціальних, політичних, економічних та інших процесів на макрорівні.

Висновки. За отриманими результатами можна визначити, що в цілому більшість індикаторів свідчить про складні зовнішні умови функціонування інституту банкрутства, 3 певним покращенням ситуації в останні роки. У зв'язку з цим виникає необхідність у подальшій трансформації інституту банкрутства, 3 метою підтримки балансу інтересів держави та господарюючих суб'єктів, а також конкурентного ринкового середовища та мінімізації ризику підприємницької діяльності.

Ключові слова: інститут банкрутства, українська економіка, криза, світова економіка, зовнішнє середовище, державна політика. 
Introduction. The general state of the economic and social situation of Ukrainian economy in the second decade of the twentyfirst century provokes attention of economists (both theorists and practitioners) to various measures that are used to overcome unfavorable trends in the development of national economy. One of such measures is managing the processes of the national economy in order to increase the bankruptcy institute effectiveness. It is precisely at the time of its formation that specific features of crisis phenomena in social and economic systems appear.

At that, the macroeconomic environment in the country has a significant impact on the nature of national systems' insolvency regulation, defining their goals and objectives. On the other hand, the current state of many Ukrainian enterprises is also directly related to the global economic crisis, which results in incomplete production capacities utilization or shutdown of production that, in its turn, leads to business solvency decrease. Therefore, there is an issue of development and implementation of certain measures to support Ukrainian enterprises in the conditions of national economy dependence on world market fluctuations, and inflation growth, in order to ensure the stability of business entity functioning in all spheres of the economy.

Under such circumstances, bankruptcy institute effective functioning becomes of particular importance, since the possibility of industrial production growth, employment level increase and people life quality improvement depends on the financial recovery of real sector economy enterprises. It should be noted that in practice there are a lot of researches on the identification of bankruptcy at the micro level, but there are few approaches to determining the features of the bankruptcy institute functioning at the state level. That is why, in modern conditions of development of Ukraine's national economy as a subject of the world economic system, it is very important to study the external conditions of the bankruptcy institute functioning.
Actual scientific researches and issues analysis. The bankruptcy institute theoretical and practical aspects research is a subject of unfailing interest of numerous native and foreign scholars and economists, among which are: S. Altman [1], I. Blanka [2], T. Vnukovs 'ka [3], L. Kozak [4], N. Karachy`na, O. Savicz ka [5], L.Ligonenko [6], J. Ohlson [7], A. Subbot [8], Ye. Rudenko [9] and others. An issue of the analysis of various aspects of bankruptcy institute functioning have been repeatedly studied in works of native scientists. Thus, negative impact of this phenomenon on the unemployment growth is highlighted in the work of O. Kravchenko [10], while works of I. Trots $[11 ; 12]$ are devoted to economic directions for enterprises bankruptcy prevention, yet the definition of tax system competitiveness as a condition for the effective bankruptcy institute functioning is researched by such scholars as I. Bezpal'ko [13] and V. Korotun [14].

Highly appreciating the contribution of all abovementioned scientists and results of their researches, it should be noted that there is a need for further thorough research of existing conditions for the bankruptcy institute functioning in the Ukrainian economy, especially if existing in the $21 \mathrm{st}$ century specificity of Ukraine's economic system development is taken into account, as well as the focus on the inclusion of national enterprises in global reproductive processes.

Aim and tasks. The aim of the study is to investigate the external conditions of bankruptcy institute functioning and their current transformation in the economy of Ukraine. The obtained conclusions will determine what exactly should be done in the direction of further improvement of the regulatory instruments of state policy in this area.

The statement of basic materials. The world economy, national economies, industries, and enterprises are complex, unstable, dynamic socio-economic systems. These systems are self-organizing, and cyclicality and crises are their natural development. The period of crises is characterized by volumes of production and business activity decrease, fall in prices, 
which is an objective prerequisite for the bankruptcy of many business entities. It should be noted that the macroeconomic environment is objective for the bankrupt enterprise. And external factors are the most threatening because the ability to influence them at the enterprise level is very small, but the consequences can be devastating.

The main external factors are: economic (inflation rate, unemployment rate, tax rate, the quantity of taxes, etc.); political, caused by actions and intentions of central and local authorities, presence of different groups of influence in government and economic authorities; market (trends of demographic factors changes, level of competition, etc.); technological, caused by the influence of scientific and technological progress on country's economy; international, associated with the globalization of economy, activity of TNCs, economic and other associations. Accordingly, improvement in one of these areas, which is primarily due to state interference, has a positive effect on the economic activity of enterprises. The bankruptcy of an enterprise does not happen in a moment, it can be caused by a combination of various factors, both internal and external. It is the state that must create the corresponding conditions, on the one hand, for the effective functioning of the enterprises, and on the other hand for maximum use of possibilities of financial recovery, including the bankruptcy procedure [15].

As it is already mentioned in previous research, in the $21 \mathrm{st}$ century, the state and society are becoming more interested not in liquidation of the debtor, but in restoring of its solvency through special procedures provided by the bankruptcy law. Thus, the bankruptcy institute also has a regulatory function, because it stipulates the implementation of measures to restore the solvency of insolvent market players. It is also necessary to understand that a bankruptcy institute is a specific form of organization of social activity and social relations that embodies norms of economic, political and legal life of society, as well as the rules of life and people behavior.
Therefore, this institute cannot be considered only from an economic or legal point of view, isolated from problems of social, political and organizational country's economic development.

This way, in order to identify the external conditions of bankruptcy institute functioning in the Ukrainian economy, it is suggested to use certain indicators (quantitative or qualitative) that directly or indirectly determine the effectiveness of bankruptcy institute, the laws of its development and the interaction of social, political, economic and other processes at the macro level. To achieve the goal of the study, it is researched in details their dynamics over the last ten years (Table 1).

In this aspect, improvement of the conditions for entrepreneurship development is one of the main directions of state policy. Reformation should be directed to a large number of spheres, the improvement of which will stimulate business activity in the country. Certain steps have already been taken in Ukraine, and by the results of 2018 the country had taken \#76 ranking, up by 4 points compared with \#80 ranking in 2017 (see Table 1). This was due to the introduction of regulatory indulgence in construction and taxation sphere, in particular, thanks to the Law No. 1817, which regulates the sphere of urban development, as well as to the reduction of the UST rate by half, to $22 \%$. But reformation is needed for numerous questions, thus according "Establishment of Enterprises" ranking in 2018, the rating has fallen on 32 positions (from 20 to 52). The index "Protection of minority investors" decreased by 11 points (from 70 to 81 ); "Receiving loans" downed for 9 points (from 20 to 29); "International trade" - for four positions (from 115 to 119) and one position Ukraine lost in the categories "Registration of ownership" (from 63 to 64) and "Implementation of contracts" (from 81 to 82).

The next indicator, which characterizes the external conditions of the bankruptcy institute functioning, is the Index of Economic Freedom estimated by the Heritage Foundation (HF). 
According to its developers, it provides an opportunity to measure the degree of economic freedom of the country and gives the possibility to compare even such different countries like Hong Kong and North Korea (for more details [15]). Unfortunately, until 2016 by this index, Ukraine remained in the group of countries with a "non-free economy", but in 2017 Ukraine moved into a group of countries with "mostly non-free economy" and positioned 149-th place from 180 , due to the improvement of the result by 3.8 points for a year. Consequently, there is a gradual improvement of the situation with the court system independence and fiscal freedom.

Table 1. Basic indicators, characterizing external conditions of bankruptcy institute functioning in the Ukrainian economy

\begin{tabular}{|c|c|c|c|c|c|c|c|c|c|c|c|}
\hline № & Indicator & $\underset{\mathscr{O}}{\tilde{O}}$ & ฮั) & $\stackrel{\sim}{\Theta}$ & $\stackrel{\widetilde{\Xi}}{\Xi}$ & $\underset{\stackrel{N}{\mathbf{N}}}{\mathbf{S}}$ & $\begin{array}{l}\tilde{\Theta} \\
\vec{\omega}\end{array}$ & $\underset{\mathscr{E}}{\tilde{E}}$ & 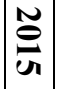 & $\stackrel{\widetilde{\sigma}}{\sigma}$ & $\stackrel{N}{\Xi}$ \\
\hline 1 & Doing business, ranking & $\vec{D}$ & $\vec{E}$ & $\nexists$ & $\overrightarrow{\vec{A}}$ & $\vec{\sim}$ & $\vec{w}$ & $\bar{N}$ & ๙ & $\underset{\omega}{\infty}$ & $\stackrel{\infty}{\circ}$ \\
\hline 2 & Economic Freedom of the World Index, EFW ranking & $\vec{\sim}$ & $\overrightarrow{\mathrm{N}}$ & $\overrightarrow{\mathfrak{N}}$ & $\overrightarrow{\mathfrak{w}}$ & $\overrightarrow{\mathfrak{\omega}}$ & $\vec{\Omega}$ & $\overrightarrow{u_{u}}$ & $\overrightarrow{\mathrm{N}}$ & $\overrightarrow{\mathrm{N}}$ & $\vec{t}$ \\
\hline 3 & Corruption perception index, points & $\ddot{o}$ & $\tilde{a}$ & $\infty$ & $\sim$ & a & $\tilde{u}$ & $\tilde{a}$ & $\sim$ & No & $\ddot{o}$ \\
\hline 4 & $\begin{array}{l}\text { Unemployment level } \\
\text { (in \% to the economically active population aged } 15-74 \text {, for Ukraine } \\
\text { - at the age of } 15-70 \text { ) }\end{array}$ & ôे & $\ddot{a}$ & $\underset{\infty}{\infty}$ & $\infty$ & $\infty$ & $\because$ & $\stackrel{\bullet}{\sim}$ & $\begin{array}{ll}0 \\
\sim\end{array}$ & $\circlearrowleft$ & $i$ \\
\hline 5 & Tax burden level, $\%$ & $\stackrel{\omega}{ \pm}$ & 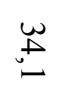 & $\begin{array}{l}w \\
w \\
\sim \\
\infty\end{array}$ & $\mid \begin{array}{l}w \\
w \\
\dot{0} \\
\infty\end{array}$ & $\mid \begin{array}{l}\omega \\
\infty \\
\infty\end{array}$ & $\begin{array}{l}w \\
w \\
\infty\end{array}$ & $\begin{array}{l}\stackrel{w}{+} \\
\stackrel{+}{0} \\
\ddot{u}\end{array}$ & $\begin{array}{l}\omega \\
0 \\
0 \\
-\end{array}$ & $\underset{\omega}{\infty}$ & $\stackrel{N}{\sim}$ \\
\hline 6 & Tax revenues to the consolidated budget, million UAH & $\underset{\substack{+\\
}}{\stackrel{N}{+}}$ & $\begin{array}{l}\text { : } \\
\stackrel{\infty}{\infty} \\
\stackrel{\omega}{\omega}\end{array}$ & $\begin{array}{l}n \\
\hat{A} \\
\stackrel{+}{E}\end{array}$ & 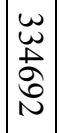 & 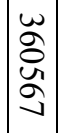 & 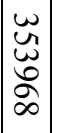 & $\begin{array}{l}\mathscr{U}_{\Delta} \\
\stackrel{u}{N}\end{array}$ & $\begin{array}{l}u \\
0 \\
a \\
\vdots \\
\sigma\end{array}$ & 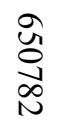 & $\begin{array}{l}\infty \\
\infty \\
\infty \\
\text { Ŭ }\end{array}$ \\
\hline 7 & Number of business entities, units & 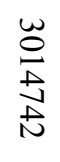 & 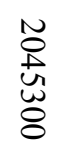 & $\begin{array}{l}N \\
\infty \\
w \\
\mathbb{D} \\
\infty \\
\infty\end{array}$ & 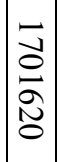 & $\begin{array}{l}\vec{a} \\
\stackrel{8}{\delta} \\
\underline{v} \\
\underline{v}\end{array}$ & $\left|\begin{array}{l}\vec{N} \\
\mathbb{N} \\
O \\
0 \\
0\end{array}\right|$ & $\begin{array}{l}\underset{\bullet}{\omega} \\
\underset{\sigma}{\sigma}\end{array}$ & 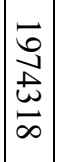 & 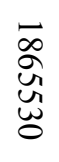 & 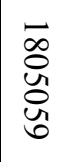 \\
\hline 8 & National taxes, (quantity) & $\tilde{\sigma}$ & $\tilde{\sigma}$ & $\widetilde{O}$ & No & $\infty$ & $\infty$ & $u$ & $u$ & $u$ & u \\
\hline
\end{tabular}

Note: source compiled by authors according to $[16 ; 17 ; 18 ; 19]$

Effective development of Ukraine's economy is hampered by the shadow character of some of its part, as it is evidenced by the Corruption Perceptions Index, which is an indicator calculated by Transparency International since 1995 on the basis of surveys involving analysts from different institutions such as the World Bank, the Swiss non-governmental organization World Economic Forum, the Economist Intelligence Unit, the US non-governmental organization Freedom House, Political Risk Services, and the African Development Bank. Countries are ranked by the scale starting from 0 (high corruption) to 100 (free from corruption, very clean). In accordance with developers approach, countries with the best the ranking are characterized by the highest level of press freedom, access to the information on budget, personal responsibility of government employees. In its turn, countries with the worst indices are characterized by an insufficient level of media independence, the unfairness of management and unreliable state institutions [20]. It is worth mentioning that the corruption, as one of the biggest global problems, has long attracted great attention worldwide. 
For example, it is seen as a major obstacle to economic development [21; 22]. So far, Jim Yong Kim the World Bank president said that corruption is "a social enemy in developing countries." [23] Considering that corruption exists in all countries and at all levels of society, and that it affects economic, political and social indicators of the country, setting on edge such problems as inequality and poverty, the improvement of the ranking, which in recent years has not nearly changed (see Table 1), is a topical issue for Ukrainian society.

The next indicator characterizing external conditions of bankruptcy institute functioning is an unemployment rate. It is believed that there is a certain dependence between the performance of bankruptcy institute functioning and dynamics of unemployment in the country. For example, the results of $O$. Kravchenko research reveale a direct relation between these categories, that is, the number of unemployed by $45 \%$ depends on the number of insolvent enterprises [10].

Analyzing the data presented in Table 1, it can be noticed a significant increase in unemployment level in 2014 from $7.7 \%$ to $9.7 \%$, which has not yet diminished. First of all, it is caused by the crisis in the Ukrainian economy, in this situation, the natural solution for many companies is the reduction of production and staff. Crisis phenomena in 2013-2014 is related first of all with a decrease in demand on Ukrainian products and unfavorable prices on international commodity markets in condition of a significant dependence of domestic enterprises on foreign markets; weakening of the financial state of domestic enterprises and cost supplement of domestic products; executing of antiterrorist operation in Donetsk and Luhansk regions, which resulted the shutdown of production of the most enterprises of these regions [24].

Another indicator that describes external conditions of bankruptcy institute functioning is the tax burden. This index reflects tax policy effectiveness on a macroeconomic scale, and also characterizes the state's activity in the taxation of economic entities business activity [25] within the framework of the chosen tax policy. If a country has a high level of the tax burden, it slows down GDP growth, reduces economic activity, and also contributes to the capital outflow abroad.

On the other hand, if the tax burden is reduced to an extremely low level, then there is a possibility whereby the budget of the country doesn't draw enough funds and, accordingly, is not able to finance the economic and social development programs of the country. Therefore, it is necessary to achieve a balance between the interests of taxpayers regarding their solvency and interests of the state regarding the budget replenishment.

To identify the dynamics of tax burden index, firstly, it is required to analyze the effect of total tax revenues on the main indicators of macroeconomic development. Analysis of these indicators in 2008-2017 shows there is an increase in the consolidated budget revenues and a decrease in the total tax burden, which can be interpreted as some positive changes in the functioning of the national economy (Table 1).

Another important indicator characterizing the external environment of the bankruptcy institute functioning is the number of business entities. It is worth mentioning that in world practice, the number of new enterprises shows the business climate in the country and describes the general economic situation. It is necessary to emphasize that in the Ukrainian economy, the number of business entities for researched period study decreased by more than 1.5 times (Table 1). But it should be also noted, the sphere of economic activity of new enterprises changed dramatically under the influence of the world economic system innovative development. Considering the fact that in Ukraine the number of registration of modern technological enterprises and virtual firms grows, the issue of appropriate adaptation of bankruptcy institute instruments and objectives becomes urgent. 
For example, the crisis of the 2000s, caused by a sharp decline in information technology industries, hit all developed countries (the USA, Western Europe, Japan), and showed the failure of existing bankruptcy systems to solve effectively the problem of business insolvency in such industries. Consequently, it is necessary to formulate universal approaches to the definition of the bankruptcy institute goals that take into account the current economic realities and protect the interests of Ukrainian society as a whole.

To summarize, despite the increase in the number of bankruptcy cases in 2014, there is a slow annual GDP growth (Fig. 1).

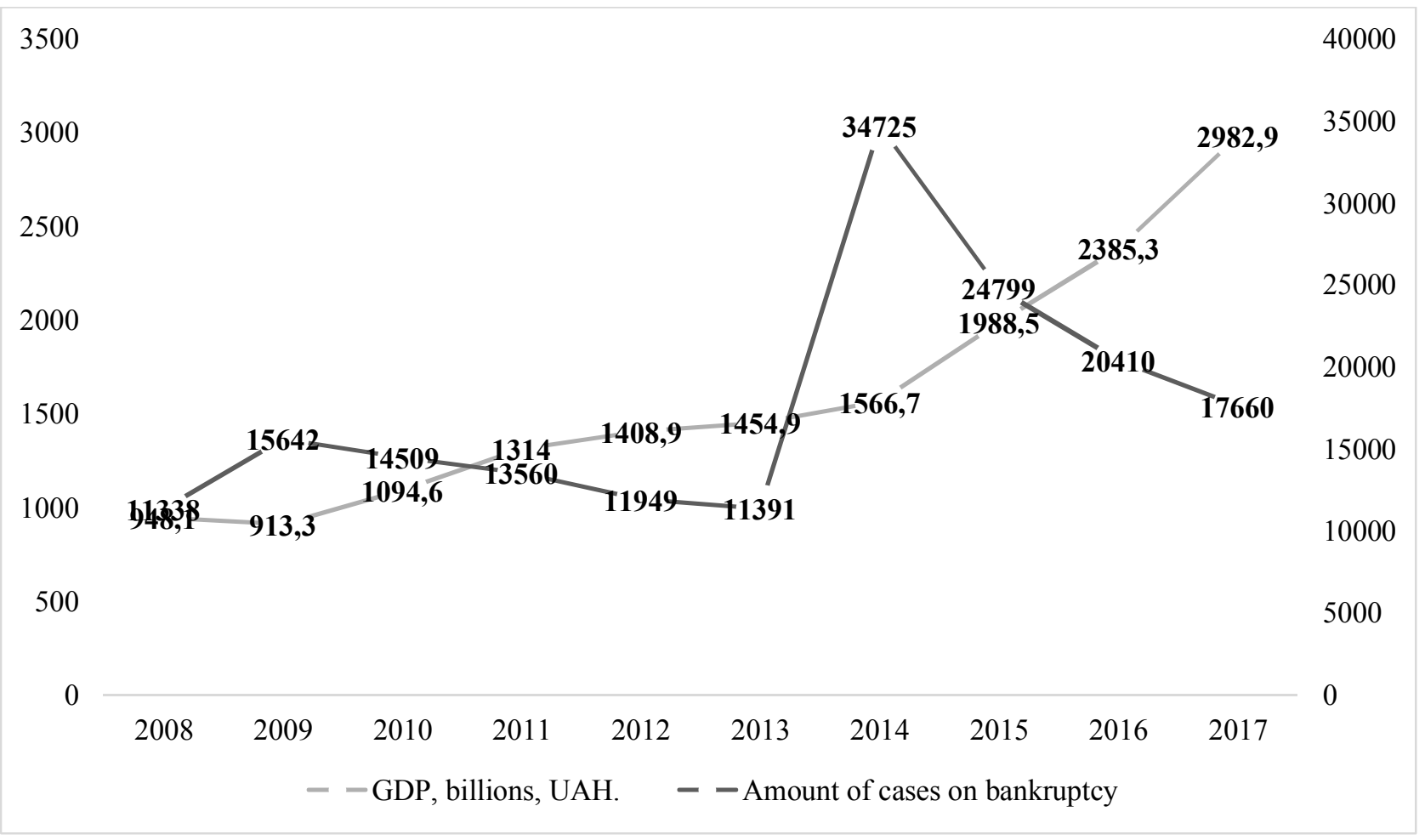

Fig.1 The dynamics of GDP and the number of bankruptcy cases in Ukraine, 2008-2017 Note: source compiled by the authors according to [16]

Unfortunately, information on enterprises bankruptcy is rather closed, and the lack of current information on the bankruptcy is one of the acute issues that is needed to be solved. Therefore, to substantiate the direction of state regulation, it is important to study the interdependence between the analyzed above indicators, which characterize the external conditions of bankruptcy institute functioning and the GDP volume, considering the change of insolvent enterprises number.
Conclusions. As a result of a study of external conditions of the bankruptcy institute functioning in the Ukrainian economy, it is determined that the existing macroeconomic environment has a significant impact on the nature of it's functioning, defining the goals and objectives of further regulation of the transformation processes. A goal of modern state functioning is to ensure sustainable economic growth that is the basis for population well-being improvement measures. 
To achieve this goal, each state builds its own individual economic policy using regulatory, legislative, economic and administrative instruments to influence business entities and other organizations maximizing the effect from available resources use and possible outcome. It is also defined that external factors of the macroeconomic environment are the most threatening due to the almost total absence of opportunity to influence them at the enterprise level. And it is proposed to consider as the most threatening the following factors: the global economic crisis; deterioration of the country international position in the world rankings; political instability of society; radical change of state foreign economic policy direction; deterioration of the socioeconomic situation; imperfection of investment policy and legislative system. The bankruptcy institute is one of the key elements of economic market systems, as it affects the formation of macroeconomic proportions in employment, social security, income levels, and the creation of the gross domestic product. In the research, the peculiarities of the external conditions of bankruptcy Institute functioning in the economy of Ukraine are identified based on the use of indicators that directly or indirectly help determine the effectiveness of bankruptcy institute, the laws of its development, and interaction of social, political, economic and other processes at the macro level. On the basis of the obtained results, it can be determined that most indicators testify the difficult external conditions of bankruptcy Institute functioning, especially in 2013-2015, meanwhile, from 2016 there is a certain improvement of the situation in the country. Thereby, there is a need for further bankruptcy institute transformation, in order to maintain the balance between the interests of the state, economic entities, competitive market environment, and entrepreneurial activity risk minimization. Finding a solution to this problem will be highlighted in future authors' research.

\section{REFERENCES}

1. Altman, E. I. (2000). Predicting financial distress of companies: revisiting the Z-score and ZETA models. Stern School of Business, New York University, 9-12.

2. Blank, IA, Goritskaya, N., Grinev, A., Yastremskaya, O., Radova, L., \& Cherep, A. (2010). Financial strategy in the system of management by the enterprise. [in Ukraine]

3. Vnukovskaya, T. (2012). Modern Economics: An Analysis of the State and Prospects of Development. Book 2. Stavropol: Logos. [in Russian]

4. Kozak, L., \& Fedoruk, O. (2010). Institute of bankruptcy as an integral part of a market economy. Project Management, Systems Analysis and Logistics, (7), 290-294. Retrieved from: http://nbuv.gov.ua/UJRN/Upsal_2010_7_73 [in Ukraine]

5. Karachyna, N., \& Savitska, O. (2014). Crisis management: modern categorical measurement. Economy. Management. Innovations, (1), 463-472. [in Ukraine]

6. Ligonenko, L.O. (2011). Bankruptcy and sanation of business entities in Ukraine: monograph. K.:KNUTE. [in Ukraine]

7. Ohlson, J. (1980). Financial ration and the pro, abilistic of bankruptcy. Journal of Accounting Research, 18(1), 118.

8. Subbot, A. (2014). Ways to Improve the Mechanism of Bankruptcy Procedure in Ukraine on the Basis of International Experience. Viche, (18), 24-28. Retrieved from: http://www.viche.info/journal/4414/ [in Ukraine] 
9. Rudenko, Ye. M. (2014). Current trends of bankruptcy in Ukraine and measures insolvency domestic enterprises. Scientific Journal of Kherson State University, 5 (3), 21-25. [in Ukraine]

10. Kravchenko, O. (2017). The dynamics of enterprise bankruptcy and unemployment level. Young Scientist, 43(3), 693-697. [in Ukraine]

11. Trots, I. (2014). Statistical review of bankruptcy of Ukrainian enterprises: national and regional aspects. Socio-Economic Research Bulletin, (3), 170-178. [in Ukraine]

12. Trots, I. (2011). Definition of the concept of bankruptcy and the reasons for its occurrence in modern conditions of development. Herald of the Dnepropetrovsk National University, (5), 221-228. [in Ukraine]

13. Bezpal'ko, I. (2015). Analysis of the competitiveness of tax system of Ukraine in the modern globalization conditions. Efektyvna ekonomika, (10). Retrieved from: http://www.economy.nayka.com.ua/pdf/10_2015/26.pdf. [in Ukraine]

14. Korotun V. (2013). Competitive tax policy formation in current globalizations processes. Retrieved from: http://ir.asta.edu.ua/jspui/bitstream/doc/201/1/168_IR.pdf. [in Ukraine]

15. Ilkova, N. (2018). Macroeconomic aspects of the bankruptcy institute's functioning. Economic space, (133), 57-68 [in Ukraine]

16. State Statistics Service of Ukraine. Retrieved from: http://www.ukrstat.gov.ua/.

17. World Bank Group. (n.d.). Doing Business. Data and Rankings. Retrieved from: http://www.doingbusiness.org

18. The Heritage Foundation (n.d.). Index of Economic Freedom Retrieved from: www.heritage.org/index/ country/ukraine

19. Transparency International (n.d.). Retrieved from: http://cpi.transparency.org/

20. Xiao, Y., Lenzen, M., Benoît, Norris, C., Norris, G. A., Murray, J., \& Malik, A. (2018). The corruption footprints of nations. Journal of Industrial Ecology, 22 (1), 68-78.

21. Kaufmann, D. (1997). Corruption: the facts. Foreign policy, 114-131.

22. Lambsdorff, J. G. (2004). How corruption affects economic development. Global Corruption Report, 310, 212.

23. World Bank (2013). Corruption is "public enemy number one" in developing countries, says World Bank Group President Kim. Retrieved from: www.worldbank.org/en/news/pressrelease/2013/12/19.

24. Duhinets, G., \& Tronko, V. (2015). Deep and Comprehensive Free Trade Area between Ukraine and EU (DCFTA): Realities and Prospects. Economic Annals-XXI, 155(11-12), 10-13. [in Ukraine]

25. Savchenko, A., \& Blyshchyk, L. (2018). Analysis of tax load level in the context of the implementation of european standards in the national economy of ukraine. Ekonomika ta derzhava, (5), 93-96. [in Ukraine] 


\section{ЛІТЕРАТУРА}

1. Altman E. I. et al. Predicting financial distress of companies: revisiting the Z-score and ZETA models. Stern School of Business, New York University. 2000. pp. 9-12.

2. Бланк I. А. та ін.. Фінансова стратегія у системі управління підприємством. 2010. 720 с.

3. Внуковская, Т. Н. Современная экономика: анализ состояния и перспективы развития: монография. Ставрополь: Логос. 2012. 188 с.

4. Козак Л. С., Федорук О. В. Інститут банкрутства як невід'ємний елемент ринкової економіки. Управління проектами, системний аналіз і логістика. Технічна серія. 2010. №. 7. С. 290294. URL: http://nbuv.gov.ua/UJRN/Upsal_2010_7_73

5. Карачина Н. П., Савіцька О. О. Антикризисное управление: современное категориальное измерение //Економіка. Управління. Інновації. 2014. №. 1. С. 463-472.

6. Лігоненко Л. О. Банкрутство та санація суб'єктів господарювання в Україні: монографія //К.: Київ. нац. торг.-екон. ун-т. 2011.

7. Ohlson J. Financial ration and the pro, abilistic of bankruptcy //Journal of Accounting Research. 1980. T. 18. №. 1. C. 118.

8. Суббот А. Шляхи вдосконалення механізму процедури банкрутства в Україні на основі міжнародного досвіду. Віче. 2014. №. 18. С. 24-28. URL: http://www.viche. info/journal/4414.

9. Руденко С. М. Сучасні тенденції банкрутства в Україні та заходи запобігання неплатоспроможності вітчизняних підприємств. Науковий вісник Херсонського державного університету. Сер.: Економічні науки. 2014. №. 5 (3). С. 21-25.

10. Кравченко О. О. Динаміка банкрутства підприємств та рівень безробіття. Young Scientist. 2017. Т. 43. №. 3. С.693-697.

11. Троц І. В. Статистичний огляд банкрутства українських підприємств: національний та регіональний аспект. Вісник соціально-економічних досліджень. 2014. №. 3. С. 170-178.

12. Троц I. В. Визначення поняття банкрутства та причини його виникнення у сучасних умовах розвитку. Вісник Дніпропетровського університету. 2011. №. 5. С. 221-228.

13. Безпалько I. Р. Аналіз конкурентоспроможності податкової системи України в сучасних глобалізацій них умовах. Ефективна економіка. 2015. №. 10. URL: http://www.economy.nayka.com.ua/pdf/10_2015/26.pdf.

14. Коротун В. І. Формування конкурентоспроможної податкової політики України в умовах глобалізації. - 2013. URL: http://ir.asta.edu.ua/jspui/bitstream/doc/201/1/168_IR.pdf.

15. Ількова Н. В. Макроекономічні аспекти функціонування інституту банкрутства. Економічний простір. - 2018. - №. 133. С. 57-68.

16. Офіційний сайт Державноії служби статистики Украіїни.

URL: http://www.ukrstat.gov.ua/.

17. Doing Business. Data and Rankings. The World Bank Group.

URL: http://www.doingbusiness.org

18. The Heritage Foundation: Index of Economic Freedom. URL: www.heritage.org/index/ country/ukraine

19. Transparency International. URL: http://cpi.transparency.org/

20. Xiao Y. et al. The corruption footprints of nations. Journal of Industrial Ecology. 2018. Vol. 22. №. 1. pp. 68-78.

21. Kaufmann D. Corruption: the facts. Foreign policy. 1997. pp. 114-131.

22. Lambsdorff J. G. How corruption affects economic development. Global Corruption Report. 2004. N. 310. pp. 212.

23. Corruption is "public enemy number one" in developing countries, says World Bank Group President Kim. URL: www.worldbank.org/en/news/press-release/2013/12/19.

24. Дугінець Г. В., Тронько В. В. Поглиблена та всеохоплююча зона вільної торгівлі (3ВТ+) між Україною та СС: реалії і перспективи. Економічний часопис-XXI. 2015. №. 155. С. 10-13.

25. Савченко А. М., Блищик Л. В. Аналіз рівня податкового навантаження в контексті імплементації європейських стандартів у національну економіку України. Економіка та держава. 2018. №. 5. С. 93-96. 